NBER WORKING PAPER SERIES

\title{
LESSONS FROM THE DEBT-DEFLATION THEORY OF SUDDEN STOPS
}

\author{
Enrique G. Mendoza \\ Working Paper 11966 \\ http://www.nber.org/papers/w11966 \\ NATIONAL BUREAU OF ECONOMIC RESEARCH \\ 1050 Massachusetts Avenue \\ Cambridge, MA 02138 \\ January 2006
}

The views expressed herein are those of the author(s) and do not necessarily reflect the views of the National Bureau of Economic Research.

(C2006 by Enrique G. Mendoza. All rights reserved. Short sections of text, not to exceed two paragraphs, may be quoted without explicit permission provided that full credit, including (C) notice, is given to the source. 
Lessons From the Debt-Deflation Theory of Sudden Stops

Enrique G. Mendoza

NBER Working Paper No. 11966

January 2006

JEL No. F41, F32, E44, D52

\begin{abstract}
$\underline{\text { ABSTRACT }}$
This paper reports results for a class of dynamic, stochastic general equilibrium models with credit constraints that can account for some of the empirical regularities of the Sudden Stop phenomenon of recent emerging markets crises. In these models, credit constraints set in motion Irving Fisher's debt-deflation mechanism and they bind as an endogenous equilibrium outcome when agents are highly indebted. The quantitative predictions of these models yield three key lessons: (1) Sudden Stops can occur as an endogenous response to typical realizations of adverse shocks to fundamentals, in environments in which agents plan their actions taking credit constraints and expectations of Sudden Stops into account. (2) Credit constraints cause output declines during Sudden Stops when collateral constraints limit debt to a fraction of the market value of capital, when there are limits on access to working capital, or when debt-deflation lowers the value of the marginal product of factors of production. (3) The debt-deflation mechanism has significant quantitative effects in terms of the amplification, asymmetry and persistence of the responses of macroeconomic aggregates to standard shocks, and in the occurrence of Sudden Stops as infrequent events nested within regular business cycles. Precautionary saving rules out the largest Sudden Stops from the stochastic stationary state, but Sudden Stops remain a positive-probability event in the long run.
\end{abstract}

\author{
Enrique G. Mendoza \\ Department of Economics \\ 3105 Tydings Hall \\ University of Maryland \\ College Park, MD 20742 \\ and NBER \\ mendozae@econ.umd.edu
}


Lessons from the Debt-Deflation Theory of Sudden Stops

By Enrique G. Mendoza*

The "Sudden Stop" phenomenon of the recent emerging markets crises is one of the key new questions facing International Macroeconomics. Sudden Stops are defined by unusually large recessions marked by: sharp, abrupt current account reversals, large contractions in output and absorption, and collapses in goods and asset prices. In Mexico's 1995 Sudden Stop, for example, the current account shifted by nearly 9 percentage points of GDP, and consumption, investment and output fell by magnitudes that exceeded their business cycle standard deviations by almost a factor of 3 . Only the Great Depression shows a recession with comparable magnitudes in the country's economic history.

The dominant paradigms of the early 1990s, International Real Business Cycle Theory (IRBC) and the New Open Economy Macroeconomics, were unable to explain Sudden Stops because they assume a perfect global credit market that allows households to smooth consumption, and firms to finance production and investment efficiently. For example, small open economy (SOE) models in the IRBC tradition predict that, when a negative, transitory shock hits total factor productivity (TFP), households borrow to smooth consumption, firms keep investment plans unaltered, and the current account falls slightly. If the shock has some persistence, households borrow less and adjust consumption more, and firms cut investment and production, resulting in regular, countercyclical current account fluctuations. Indeed, SOE-IRBC models proved quite good at mimicking the business cycles of industrial economies.

Sudden Stops are strikingly different. At the time that output experiences Great-Depression-size declines, the current account takes an abrupt jump up and domestic absorption plummets. Just when the dominant paradigms predict that agents need capital markets the most, agents cannot borrow at all.

A growing literature aiming to explain Sudden Stops emerged in recent years. The starting point of this literature is to replace the assumption of perfect credit markets with plausible financial frictions. Despite important progress in theoretical work, three key issues are still unresolved:

(a) Sudden Stops are modeled as large, unexpected shocks. In most Sudden Stop models (for example, Guillermo A. Calvo (1998), V.V. Chari et al. (2005)), current account reversals are a surprise -a large, sudden exogenous shock to foreign borrowing. This assumption has several unappealing implications: First, the defining feature of Sudden Stops (the abrupt current account reversal) remains unexplained. Second, agents are not allowed to make optimal plans considering the probability that Sudden Stops may occur. Third, we cannot tell whether the predictions of particular models are robust to changes allowing agents to act on expectations of Sudden Stops. Precautionary savings theory suggests that this can be a flaw because, when faced with possible catastrophic events, agents build a buffer stock of savings to lower the long-run probability of these outcomes.

(b) Sudden Stop models cannot explain the output collapse in the initial stages of a Sudden Stop. Most existing models consider financial frictions affecting consumption and/or investment, which affect output after the initial current account reversal. Moreover, growth accounting exercises (Raphael Bergoeing et al. (2002) and Enrique G. Mendoza (2005a)) show that capital and labor account for a small fraction of the initial output collapse, so even if the models could mimic observed investment collapses, they would not explain the output collapse. We should not conclude from this, however, that Sudden Stops are driven by TFP shocks unrelated to financial frictions, because there can be endogenous financial links between measured TFP (e.g. Solow residuals) and Sudden Stops. In particular, Sudden Stops feature large swings in imported input prices and capacity utilization (see David Cook and Michael B. Devereux (2006) and Mendoza (2005a)), and swings like these are easy to misrepresent as true TFP changes in standard estimates of Solow residuals (see Mary G. Finn (1995)).

(c) The quantitative relevance of financial mechanisms driving Sudden Stop models is largely unknown. Narayana Kocherlakota (2000) casts doubt on the ability of credit constraints to yield sizable asymmetry, 
amplification and persistence in the responses of macroeconomic aggregates to adverse shocks. Moreover, because of the scarcity of quantitative findings, we cannot tell whether a financial friction with reasonable Sudden Stop features can produce Sudden Stops as infrequent events nested within typical fluctuations, as observed in the data. The structure of emerging economies does not change abruptly when they hit a Sudden Stop, so a theory that could explain Sudden Stops by introducing frictions that result in unrealistic business cycles would not be very helpful. It is equally important to distinguish mechanisms that enlarge "typical" business cycle variability from mechanisms that create Sudden Stops. Chari et. al (2005) mix the two in referring to Pablo A. Neumeyer and Fabrizio Perri's (2005) model of large business cycles driven by large interest rate shocks as a model of Sudden Stops. Sudden Stops are not observable in standard business cycle moments because unusually large recessions are, by definition, swamped by typical cycles.

This paper reports results for a class of equilibrium models with credit constraints that aim to make progress in addressing the above problems. The two key features common to these models are that: whether the credit constraints bind is an endogenous equilibrium outcome, and when they bind, they set in motion Irving Fisher's (1933) debt-deflation mechanism. This mechanism induces nonlinear feedback between a country's access to credit and the prices and allocations of goods and assets on which debt is leveraged. Several theoretical articles in the Sudden Stops literature study models with the debt-deflation mechanism (see Cristina Arellano and Mendoza (2003) for a limited survey). The contribution of the models reviewed here is the quantitative analysis of this mechanism in a dynamic, stochastic general equilibrium (DSGE) framework.

The quantitative debt-deflation models of Sudden Stops yield three key lessons:

(1) Sudden Stops emerge endogenously without large, unexpected shocks. They are an endogenous outcome in environments in which agents plan their actions taking credit constraints and expectations of Sudden Stops into account. A Sudden Stop is an equilibrium response to typical realizations of adverse shocks to fundamentals (e.g. world interest rates, the terms of trade, or TFP) when agents are highly indebted. In turn, these high-debt states are reached with positive probability in the long run as a result of the equilibrium dynamics of the economy.

(2) Collateral constraints do cause output declines during Sudden Stops. Output falls on impact when a Sudden Stop begins if credit constraints limit access to working capital, or if the debt-deflation mechanism lowers the value of the marginal product of factors of production. In addition, contrary to the

findings of Chari et al. (2005), output does fall after an initial current account reversal in the presence of endogenous collateral constraints that limit debt to a fraction of the market value of physical capital.

(3) The quantitative effects of the debt-deflation mechanism are important. This mechanism yields significant amplification and asymmetry in the responses of macro variables to standard shocks. In addition, Sudden Stops are infrequent events nested within regular business cycles. If the credit constraints do not bind, the economy responds to adverse shocks as SOE-DSGE models predict. Precautionary saving rules out the largest Sudden Stops from the stochastic stationary state, but Sudden Stops remain a positive-probability event even though their effect on business cycle statistics is negligible.

\section{Debt-Deflation Models of Business Cycles and Sudden Stops}

The models are based on Mendoza's (1991) SOE-IRBC framework, which is not described in detail due to space constraints, but replacing the assumption of perfect credit markets with borrowing constraints. The models represent the decentralized competitive equilibrium of economies where the agents' ability to borrow in a world market of one-period bonds $(b)$ is limited to a fraction $\kappa$ of the market value of the income or assets offered as collateral:

$$
b_{t+1} \geq-\kappa g\left(p_{t}, y_{t}, k_{t+1}, k_{t}, b_{t}\right), \quad \kappa \geq 0
$$


The collateral function $g(\cdot)$ depends on a vector of market prices $p$ (for goods, factors, or assets), on income, $y$, on asset holdings, $k$, and on existing debt. This setup includes a wide variety of borrowing limits. At the extremes, $\kappa=0$ represents a no-borrowing constraint and $\kappa=\infty$ is the perfect-credit-markets case. When $g(\cdot)$ is a constant, the constraint is an ad-hoc debt limit. The case with $g(\cdot)=q_{t} \alpha_{t+1} k$, where $q_{t}$ is the price of equity and $\alpha_{t+1}$ are equity shares, is Rao Aiyagari and Mark Gertler's (1999) margin constraint. Kocherlakota (2000) examined the constraint $g(\cdot)=q_{t} k$, with $k$ as a factor in inelastic supply (e.g. land). The case with $g(\cdot)=y_{t}^{T}+p_{t}^{N} y_{t}^{N}$, where $y^{T}$ and $y^{N}$ are incomes from tradables and nontradables respectively and $p^{N}$ is the relative price of nontradables, is the liability dollarization credit constraint (foreign debt is in units of tradables but leveraged in part on nontradables income). The price of nontradables is endogenous and a drop in $p^{N}$ (i.e., a real depreciation) can trigger the constraint.

On the side of firms, the credit constraint (1) can represent a limit on the firms' access to working capital. For instance, $b_{t+1}$ can represent working capital loans and $g(\cdot)$ could be the firms' sales (as if these loans were trade credits guaranteed by sales) or the market value of the firms' physical assets. Constraints of this type produce a credit transmission channel that links the loss of access to world credit with an immediate drop in output, as Section II explains.

\section{A. Distortions Induced by Credit Constraints in Debt Deflation Models}

Constraints in the family defined in (1) introduce distortions akin to endogenous financing premia. In general, the consumption Euler equation of models with these constraints can be written as:

$$
\lambda_{t}=E_{t}\left[\lambda_{t+1} R\right]+\mu_{t}
$$

where $\lambda_{t}$ is the lifetime marginal utility of date-t consumption (i.e. the Lagrange multiplier on the budget constraint), $\mu_{t}$ is the Lagrange multiplier on the credit constraint, and $R$ is the world-determined real interest rate (assumed to be time-invariant for simplicity). Defining the households' intertemporal relative price of consumption as $R_{t+1}^{h} \equiv \lambda_{t} / E_{t}\left[\lambda_{t+1}\right]$, it follows that, when (1) binds, households face the following endogenous financing premium:

$$
E_{t}\left[R_{t+1}^{h}-R\right]=\mu_{t} / E_{t}\left[\lambda_{t+1}\right]
$$

In models that allow for asset accumulation, this premium alters excess asset returns as follows:

$$
E_{t}\left[R_{t+1}^{q}-R\right]=\left(\frac{\mu_{t}(1-\kappa)-\operatorname{cov}_{t}\left(\lambda_{t+1}, R_{t+1}^{q}\right)}{E_{t}\left[\lambda_{t+1}\right]}\right),
$$

where $R_{t+1}^{q}$ is the return on assets. Thus, a binding credit constraint has a direct effect that increases the equity premium by the fraction $(1-\kappa)$ of the hike in the financing premium. This effect is limited to the fraction $(1-\kappa)$ because, on the margin, agents can relax their credit constraint by holding more assets, with the marginal increase in "debt capacity" given by $\kappa \cdot{ }^{1} \mathrm{~A}$ binding credit constraint also induces the Heaton-Lucas indirect effect because the constraint hampers the ability of agents to smooth consumption, and hence makes the covariance between marginal utility and asset returns "more negative," thereby increasing excess returns. The forward solution for the households' asset valuations yields:

$$
q_{t}=E_{t}\left(\sum_{j=0}^{\infty}\left[\prod_{i=0}^{j}\left(\frac{1}{E_{t}\left[R_{t+1+i}^{q}\right]}\right)\right] d_{t+1+i}\right)
$$

where $d$ represents dividends. Expressions (4) and (5) show that a credit constraint that binds at present, or is expected to bind at any point in the future, increases excess returns and lowers asset prices bid by the agents facing the constraint. As Section II explains, however, this is necessary but not sufficient for equilibrium asset prices to fall when the credit constraints bind.

In models in which firms can hit limits on working capital, firms face a financing premium that increases effective factor costs when the limit binds. If, for example, working capital financing is available up to a fraction $\kappa^{f}$ of the value of the firms' assets at the end of the production period, the optimality condition for the demand for factor $n_{j}$ for which a fraction $\phi$ of the cost is paid with credit is: 


$$
\varepsilon_{t}^{A} F_{n_{j}}\left(N_{t}\right)=p \varepsilon_{t}^{p}\left[1+\phi\left(r+\chi_{t} R\right)\right]
$$

$F_{n_{j}}\left(N_{t}\right)$ is the marginal product of $n_{j}$ in a production function $F(N)$ that uses a vector of inputs $N, r$ is the net interest rate on working capital (i.e., $R-1), \chi_{t}$ is the Lagrange multiplier on the working capital constraint, and $\varepsilon^{A}$ and $\varepsilon^{P}$ are shocks to TFP and the market price of $n_{j}$. If $\chi_{t}=0$, condition (6) reduces to the optimality condition of SOE-IRBC models with the standard working capital setup (e.g. Neumeyer and Perri (2005)). P. Marcelo Oviedo (2005) showed that these models require interest rate processes with high mean and variance for working capital to make a difference. In contrast, when the limit on working capital binds, the marginal cost of $n_{j}$ rises because the effective financing cost of working capital goes up by $\chi_{t} R$. This endogenous financing premium amplifies the responses of factor demands to shocks, and this mechanism can be triggered by shocks to TFP or factor prices, even with a constant interest rate. Moreover, if the amplified factor demand responses make asset prices fall, the debt-deflation mechanism is set in motion because the fall in the value of the collateral tightens further the limit on working capital.

The credit constraints examined here are endogenous because they respond to equilibrium prices and allocations (as in Macroeconomics literature on credit constraints by Nobuhiro Kiyotaki and John Moore (1997), Aiyagari and Gertler (1999) or Kocherlakota (2000)), but they are not modeled as outcomes of optimal credit contracts. Still, the above financing premia represent endogenous premia, varying across time and states depending on whether the credit constraints bind and on how binding they are, which foreign lenders could charge so that borrowers find it optimal to respect the credit constraints in a credit market where the constraints are not imposed directly. ${ }^{2}$ The justification for this could be that, for example, limited enforcement prevents lenders from recovering more than $\kappa$ or $\kappa^{f}$ of the market value of a debtor's assets in case of non-repayment.

\section{B. Amplification, Sudden Stops \& Debt Deflations: A Liability Dollarization Example}

The endogenous, nonlinear feedback between price deflation and debt access sets the debt-deflation mechanism apart from other credit constraints studied in the Sudden Stops literature. This point can be illustrated with an example based on a simple deterministic, two-sector model. The model features a timeinvariant endowment of nontradables and a sequence of tradables endowment tilted towards the future (so that agents wish to borrow at present). ${ }^{3}$ With standard stationarity assumptions and perfect credit markets, the equilibrium of this economy is a textbook example of Permament Income theory: tradables consumption is perfectly smooth, nontradables consumption and the relative price of nontradables are constant, and the current account moves to keep tradables consumption as a constant fraction of wealth (with wealth equal to the present value of the tradables endowment). Add now the liability dollarization credit constraint $b_{t+1} \geq-\kappa\left(y_{t}^{T}+p_{t}^{N} y_{t}^{N}\right)$, and hit the economy with wealth-neutral shocks that reduce $y_{0}{ }^{T}$ and increase $y_{1}^{T}$. As long as the credit constraint does not bind, the equilibrium with perfect credit markets is preserved. There is, however, a critical value of $y_{0}{ }^{T}$ low enough for the constraint to bind, and below this value the frictionless equilibrium is no longer attainable.

Figure 1 illustrates the date-0 equilibrium of this debt-deflation model. The equilibrium with the credit constraint binding must satisfy two conditions: First, the resource constraint for tradables with debt set at the borrowing limit must hold (which is the case along the SS line - notice that SS shifts horizontally to the left as $y_{0}{ }^{T}$ falls). Second, $p_{0}{ }^{N}$ must equal the marginal rate of substitution between consumption of tradables and nontradables. This condition is represented by the PP curve. The line TT represents tradables consumption with perfect credit markets (or when the credit constraint does not bind), which is independent of the price of nontradables. TT and PP intersect at the equilibrium with perfect credit markets (point A). The curve SS is drawn for the critical value of $y_{0}{ }^{T}$ at which the constraint begins to bind, so SS intersects TT and PP at point A.

Assume that $y_{0}{ }^{T}$ falls below its critical level causing SS to shift to $\mathrm{SS}^{\prime}$. The new equilibrium is 
determined at point $\mathrm{D}$, and the change from $\mathrm{A}$ to $\mathrm{D}$ can be broken down into three moves. First, if prices were sticky and the borrowing constraint were set as an ad-hoc debt limit, the new equilibrium would be at point B. At B, however, tradables consumption is lower than in the perfect credit markets case and equilibrium requires $p_{0}{ }^{N}$ to fall. Thus, the second move, from B to $\mathrm{C}$, reflects the pure balance sheet effect of liability dollarization (as in Calvo (1998)). If the credit constraint were independent of the nontradables price (i.e., without debt deflation), $\mathrm{C}$ would be the new equilibrium, with a lower nontradables price and lower tradables consumption. But at $\mathrm{C}$ the debt deflation has yet to take place. Hence, the third move, from $\mathrm{C}$ to $\mathrm{D}$, occurs because the lower price at $\mathrm{C}$ tightens the credit constraint by lowering the value of the nontradables endowment. This forces tradables consumption to fall so as to satisfy the constraint at a point in $\mathrm{SS}^{\prime}$, but at that point $p_{0}{ }^{N}$ falls again to re-attain a point along $\mathrm{PP}$, but at that point tradables consumption falls again because the credit constraint tightens further. This debtdeflation process continues until it converges to point D. In short, the response to the shock hitting $y_{0}{ }^{T}$ is amplified because of the combined balance sheet and debt-deflation effects.

Two important observations about the Sudden Stop equilibrium: First, the abrupt current account reversal (i.e., the amplification of the response of the current account form $\mathrm{C}$ to $\mathrm{D}$ ) is an endogenous outcome, not an assumption. Second, the Sudden Stop occurs even with fully flexible prices and is not driven by a self-fulfilling shift across multiple equilibria.

Mendoza (2005b) conducts some numerical experiments with this basic model using parameter values set to match roughly key features of emerging economies, particularly the elasticity of substitution between consumption of tradables and nontradables. This elasticity is crucial because it determines the response of $p^{N}$ to a given contraction in tradables consumption. The results show that the debt-deflation mechanism generates substantial amplification that dwarfs the balance sheet effect. For example, setting $\kappa=0.34$, a 5 -percent wealth-neutral shock to $y_{0}{ }^{T}$ reduces the debt position by 15 percentage points of permanent income, and makes tradables consumption and $p_{0}{ }^{N}$ fall to levels nearly 60 percent below those of the equilibrium with perfect credit markets. The debt-deflation mechanism contributes all but 3 percentage points of these declines in consumption and the price of nontradables.

\section{The Quantitative Lessons \\ A. Liability Dollarization in a DSGE Model}

Mendoza (2002) examines a DSGE model with the liability dollarization credit constraint that considers production of nontradables with labor demand and supply. The credit constraint limits households' tradables-denominated debt to a fraction of their income, as is standard practice in household debt markets (where lenders use scoring algorithms to set ceilings on debt-income ratios). With a CobbDouglas production technology, this translates at equilibrium into the constraint $b_{t+1} \geq-\kappa\left(y_{t}^{T}+p_{t}^{N} y_{t}^{N}\right)$. Agents know that this constraint is a feature of the credit market and they take it into account in formulating their optimal plans. If the economy's debt is sufficiently large, the credit constraint binds as an endogenous equilibrium response to adverse one-standard-deviation (1SD) shocks to TFP, $R$, and an inflation-equivalent consumption tax. In these Sudden Stops output falls on impact because the collapse in $p^{N}$ lowers the value of the marginal product of labor, and hence labor demand.

Simulations based on a calibration to Mexican data show that the impact effects of 1SD shocks are amplified significantly during Sudden Stops. Comparing with the responses under perfect credit markets, the current account reversal is 5 percentage points of GDP larger, consumption and nontradables output fall 10 percentage points more, and the price of nontradables falls 8 percentage points more. However, agents build a large stock of precautionary savings, worth about 35 percent of GDP in terms of the mean of $b$, and with this "war chest" the long-run probability of binding credit constraints is only 0.33 percent.

The debt-deflation mechanism induces offsetting supply-side effects in this model. On one hand, labor demand falls because the value of the marginal product of labor falls with the price of nontradables. On 
the other hand, the marginal gain of labor supply rises because extra labor income allows agents to borrow more. If labor supply is sufficiently elastic, this second effect can dominate at very high debt levels (i.e., with a very tight credit constraint), but, because of precautionary savings, these states have zero long-run probability.

\section{B. Debt-Deflation Mechanics in Global Asset Trading}

The debt-deflation spiral can affect asset prices if collateral constraints affecting some agents coexist with trading frictions that produce a less-than-infinitely-elastic demand for assets from other agents. In this case, agents that hit collateral constraints and fire-sale assets in efforts to "meet margin calls," trade with agents that have downward-slopping asset demand curves. Asset prices therefore fall, and as they do the collateral constraint tightens further, setting the debt-deflation mechanism in motion (and magnifying the direct and indirect asset pricing effects of collateral constraints). If the agents fire-selling assets could trade in a frictionless, competitive market, in which market demand is infinitely elastic at the fundamentals price $q_{t}^{f}$ (i.e., the expected present value of dividends discounted at the world interest rate), asset prices could not fall and the debt-deflation mechanism could not function.

Mendoza and Smith (2006) model the asset trading friction as trading costs incurred by foreign securities firms, which may include conventional trading costs as well as costs due to informational, institutional or other intangible frictions. Mendoza and Smith study a two-agent equilibrium asset pricing setup in which domestic agents face the Aiyagari-Gertler margin constraint $b_{t+1} \geq-\kappa q_{t} \alpha_{t+1} k$. Explicit lending on margin takes place mainly amongst investors in securities markets, and regulators also impose statutory margin requirements. In addition, widely-used risk management tools (e.g. value-at-risk collateralization) operate as implicit margin requirements by making creditors sell assets and cut credit when systemic shocks increase market volatility, resulting in even higher volatility and further asset sales.

Foreign traders incur trading costs of the form: $q_{t}\left(\frac{a}{2}\right)\left(\alpha_{t+1}^{*}-\alpha_{t}^{*}+\theta\right)^{2}$, where $a$ is a trading cost coefficient and $\theta$ represents costs paid regardless of trading activity. This setup produces a closed-form solution for the foreign traders' demand function: $\left(\alpha_{t+1}^{*}-\alpha_{t}^{*}\right)=(1 / a)\left[\left(q_{t}^{f} / q_{t}\right)-1\right]-\theta$. Thus, the foreign traders' demand elasticity with respect to the percent deviation of $q_{t}^{f}$ from $q_{t}$ is $1 / a$.

Mendoza and Smith calibrate the model to Mexican data and show that it can produce Sudden Stops as endogenous responses to 1SD productivity shocks when: (a) agents are sufficiently leveraged (i.e., when $-b_{t} / q_{t} \alpha_{t} k$ is sufficiently high), and (b) the asset market is relatively liquid (i.e., when short-selling limits are not binding). ${ }^{4}$ The ability of the model to yield asset price collapses hinges, however, on the foreign traders' demand being sufficiently inelastic.

Figure 2 shows the model's conditional impulse responses (i.e., conditional forecast functions of the nonlinear equilibrium Markov processes) to a 1SD, negative TFP shock when a Sudden Stop occurs. The Figure shows simulations for an elasticity of 0.5 in the demand of foreign traders. Relative to the outcome with perfect credit markets, consumption collapses 8 percentage points more, the current account increases by 6 percentage points of GDP more, and asset prices decline by 8 percentage points more. Thus, the debt-deflation mechanism induces significant amplification effects. Moreover, the effects on consumption and the current account persist for several periods.

The size of the trading costs predicted by the model can be assessed by examining total trading costs in percent of equity returns. Trading costs are negligible, at less than $1 / 5$ of a percent of returns, when the collateral constraint does not bind, but they rise rapidly as the leverage ratio rises inside the Sudden Stop region (i.e., in the region of the state space where the constraint binds), peaking at about 6.4 percent of returns. Mendoza and Smith (2006) document findings from the finance literature suggesting that costs of this magnitude are in line with empirical evidence.

\section{The Debt-Deflation Mechanism in an Equilibrium Business Cycle Model}


The models reviewed in $A$. and $B$. are incomplete business cycle models because they abstract from capital accumulation and make strong simplifying assumptions about the supply-side of the economy (in Mendoza and Smith (2006), for example, output is unaffected by credit frictions and responds to TFP shocks just like in a frictionless economy). Mendoza (2005a) examines a business cycle model with the collateral constraint $b_{t+1} \geq-\kappa q_{t} k_{t+1}$ and a constraint limiting working capital financing to the fraction $\kappa^{f}$ of sales. Chari et al. (2005) claim that these are subtle constraints for which there is little direct evidence. Firm-level data show, however, that corporate leverage ratios rise sharply in the run up to Sudden Stops, and collapse abruptly in the aftermath (see Figure 3). There are also extensive accounts of the role played by highly leveraged agents in these events (in the famous case of the Russian crisis, massive margin calls on these agents reached even U.S. capital markets and led the Federal Reserve to lower interest rates).

In Mendoza (2005a), firms use working capital to pay for a fraction $\phi$ of the cost of imported inputs, for which they pay a world-determined price, and for costs of capacity utilization. Firms also face capital adjustment costs, so they feature a demand for investment (or supply of equity) that rises with the price of capital (i.e., Tobin's Q). This is the trading friction that makes agents fire-selling equity interact with agents that buy equity only if the price falls. When Tobin's Q falls as a result of the debt-deflation mechanism, it brings down investment, and with it future capital, output and wealth.

Mendoza (2005a) calibrates the model to quarterly Mexican data for the period 1993:1-2004:4. The model includes shocks to $R$ (the real rate on 90-day U.S. T-bills), shocks to the relative price of imported inputs, and TFP shocks. The latter are estimated using a production function for gross output that includes imported inputs and variable capital utilization, so as to correct for the bias affecting Solow residuals. Agents form their expectations using the stochastic process for these shocks taken from the data, without any large, unexpected shocks.

The results show that the key findings of the other debt-deflation models extend to the business cycle model: The debt-deflation mechanism is a powerful vehicle for inducing amplification, asymmetry and persistence in the response of real variables to exogenous shocks of "typical" size. Sudden Stops occur when households and firms have debts large enough for the credit constraints to bind, and these high-debt states are reached with positive probability in the stochastic stationary state. Precautionary saving rules out the "largest" Sudden Stops and results in a long-run probability of binding collateral constraints of 1.7 percent (low but significantly higher than in the liability dollarization and asset trading economies)

Sudden Stops occur in the model even if the limit on working capital never binds. Starting from a positive-probability Sudden Stop state where the collateral constraint binds and with $\kappa^{f}$ high enough so that $\chi_{t}=0$ always, the model predicts the following impact effects relative to the economy with perfect credit markets: an excess current account reversal of 6 percentage points of GDP, and excess drop in consumption of 2 percentage points and an excess investment collapse of 24 percentage points. Asset prices decline only by an excess of 0.5 percent, which is much less than in the data, but still implies substantial amplification relative to the frictionless case (where equity prices hardly move). Output begins to fall one period after the current account reversal, as the impact effect on investment begins to hit installed capital, and it falls by an excess of up to 2 percentage points four periods later. The Sudden Stops on investment, Tobin's Q and the current account are short-lived, but those affecting output, consumption, and labor are persistent.

Introducing a binding limit on working capital improves the above results by producing an excess output decline on impact as the Sudden Stop begins. The decline cannot account for the full magnitude of initial output collapses of actual Sudden Stops because of two limitations of the working capital constraint linked to sales. First, this constraint induces offsetting effects on factor demands: On one hand, the financing premium in (6) increases effective factor costs. On the other hand, the effective marginal benefit of employing these factors increases when the working capital constraint binds because increased factor 
demands support higher output and sales, and the latter increases the firms' ability to borrow. Second, the Cobb-Douglas production function reduces the effectiveness of the working capital constraint because the ratio of sales (i.e., output) to factor payments is unaffected by shocks to TFP or input prices, and thus is only affected by interest rate shocks. Since only a fraction of factor costs is paid with credit, and only the small interest-rate shocks reflected in the U.S. real interest rate are considered, the findings from Oviedo (2005) apply: interest rate shocks have small effects on factor demands. The effects are larger than he found because of the endogenous risk premium operating when the limit on working capital binds, but they are small compared to what is needed to explain the initial decline in output of a Sudden Stop.

\section{Further Research \& Policy Lessons}

Research in quantitative models of Sudden Stops is at an early stage and needs to move in several directions. A revision in progress of Mendoza (2005a) addresses the shortcomings of the sales-linked limit on working capital by linking it to the value of the firm's assets instead (see eq. (6)). This change also adds a new feedback channel for the debt-deflation process, since the fall in Tobin's Q now tightens the working capital constraint. The Tobin Q setup has limitations, however, because the results reviewed here suggest that it may not be able to account simultaneously for the asset price crashes and the investment collapses of Sudden Stops: the high adjustment costs that may produce the former would yield small investment declines. On a different vein, it would be interesting to explore the quantitative significance of the debt-deflation mechanism at work with the liability dollarization credit constraint in a full-blown equilibrium business cycle model. Beyond debt-deflation models, other financial frictions are producing important quantitative findings in terms of their ability to produce Sudden Stops that suggest promising areas for further research. These include search frictions in foreign investment (Guita Gopinath (2004)), the interaction of transactions costs in goods and asset markets (Philippe Martin and Helene Rey (2006)), and signal extraction frictions in asset markets with imperfectly informed agents (Emine Boz (2006)).

Debt-deflation models of Sudden Stops also have important policy lessons that are fertile ground for further research. Since debt-deflation effects are significant, it seems natural to conclude that policies aimed at preventing deflation are a good option. Fisher (1933) himself made this argument, and Calvo's (2002) proposal to provide price guarantees on the emerging markets asset class is in a similar vein. His and other recent proposals for managing Sudden Stops by containing large deviations of asset prices below their fundamentals levels can be examined using the framework described in this paper. For example, C. Bora Durdu and Mendoza (2006) explore the implications of price guarantees in the debt-deflation model of Mendoza and Smith (2006). The guarantees introduce a moral-hazard-like distortion that leads foreign traders to "overinvest" and domestic agents to "overborrow." With precise knowledge of the data, the model yields a state-contingent schedule of guarantees for which the benefit of undoing the distortions that cause Sudden Stops exceeds the costs of the moral hazard distortion. Yet, whether we have such knowledge of the data, and whether the model is a sufficiently accurate representation of reality to use it for implementing the price guarantees system, are still open questions.

The indexation of debt to GDP or to the relative prices relevant for liability dollarization, and the adoption of hard currencies to replace domestic currencies, have also been proposed as remedies for Sudden Stops, and some countries have adopted them (e.g., Argentina's GDP-linked debt or El Salvador's adoption of the dollar). However, their effectiveness at preventing Sudden Stops is yet to be tested.

If "creative" new policies seem risky, the debt-deflation models provide their own remedy: build a "war chest" of foreign exchange reserves to minimize the long-run probability of Sudden Stops. This Neomerchantilist strategy has its problems, because holding reserves is costly and in the short-run building

them up can imply a costly sacrifice (as Ricardo Caballero and Stavros Panageas (2005) showed). On the other hand, this is the strategy many emerging economies are following, and if the alternative is to be exposed to re-live the experiences of the last ten years, Merchantilism may not be so unreasonable. 


\section{REFERENCES}

Aiyagari, S. Rao and Gertler, Mark. "Overreaction of Asset Prices in General Equilibrium." Review of Economic Dynamics, 1999.

Arellano, Cristina and Mendoza, Enrique G. "Credit Frictions and Sudden Stops in Small Open Economies: An Equilibrium Business Cycle Framework for Emerging Markets Crises," in Altug, Chadha, and Nolan eds., Dynamic Macroeconomic Analysis, Cambridge University Press, 2003.

Boz, Emine. "Do Miracles Lead to Crises? An Informational Frictions Explanation of Emerging Market Financial Crises," Ph.D. diss., University of Maryland, 2006.

Bergoeing, Raphael, Kehoe, Patrick J., Kehoe, Timothy J., and Soto, Raimundo. "Decades Lost and Found," Federal Reserve Bank of Minneapolis Quarterly Review, 2002, 26 (1), pp. 3-30.

Caballero, Ricardo and Panageas, Stavros. "A Quantitative Model of Sudden Stops \& External Liquidity Management," Natl. Bureau of Econ. Research Inc., NBER Working Papers: No. W11293, 2005.

Chari, V.V., Patrick J. Kehoe, and Ellen R. McGrattan. "Sudden Stops and Output Drops." American Economic Review, 2005, 95(2), pp. 381-387.

Calvo, Guillermo A. "Capital Flows and Capital-Market Crises: The Simple Economics of Sudden Stops," Journal of Applied Economics, 1998, 1, pp 35-54.

, "Globalization Hazard and Delayed Reform in Emerging Markets," Economia, 2002, 2(2).

Cook, David and Devereux, Michael B. "External Currency Pricing and the East Asian Crisis," Journal of International Economics," forthcoming, 2006.

Durdu, C. Bora and Mendoza, Enrique G. "Are Asset Price Guarantees Useful for Preventing Sudden Stops?" Journal of International Economics, forthcoming, 2006.

Finn, Mary G. "Variance Properties of Solow's Productivity Residual and their Cyclical Implications," Journal of Economic Dynamics and Control, 1995, 19, pp. 1249-1281.

Fisher, Irving. "The Debt-Deflation Theory of Great Depressions," Econometrica ,1933, 1, pp. 337-57.

Gopinath, Gita. "Lending Booms, Sharp Reversals and Real Exchange Rate," Journal of International Economics, 2004.

Kiyotaki, Nobuhiro and Moore, John. "Credit Cycles," Journal of Pol. Economy, 1997, 105, pp. 211-248.

Kocherlakota, Narayana. "Creating Business Cycles Through Credit Constraints," Federal Reserve Bank of Minneapolis Quarterly Review, 2000, 24(3), pp. 2-10.

Martin, Philippe and Rey, Helene. "Globalization and Emerging Markets: With or Without Crash?," American Economic Review, forthcoming, 2006.

Mendoza, Enrique G. "Real Business Cycles in a Small Open Economy," American Economic Review, 1991, 81, pp. 797-818.

"Credit, Prices, and Crashes: Business Cycles with a Sudden Stop," in J. Frankel and S. Edwards eds. Preventing Currency Crises in Emerging Markets, Univ. of Chicago Press, 2002.

and Smith, Katherine A. "Quantitative Implications of a Debt-Deflation Theory of Sudden Stops \& Asset Prices," Journal of International Economics, forthcoming, 2006.

"Sudden Stops in a Business Cycle Model with Credit Constraints: A Fisherian Deflation of Tobin's Q," unpublished paper, International Monetary Fund, 2005a.

"Real Exchange Rate Volatility and the Price of Nontradables in Sudden-Stop-Prone Economies," Economia, forthcoming, 2005b.

Neumeyer, P. Andres and Perri, Fabrizio. "Business Cycles in Emerging Economies: The Role of Interest Rates," Journal of Monetary Economics, 2005.

Oviedo, P. Marcelo. "World Interest Rate, Business Cycles and Financial Intermediation in Small Open Economies," Unpublished Paper, 2005. 


\section{FOOTNOTES}

* Research Department, International Monetary Fund, 700 19th St. N.W., Washington DC, 20431, University of Maryland and NBER. I am grateful to Guillermo Calvo, Bora Durdu, and Katherine Smith, for their valuable contributions to the findings reported in this paper and to Helene Rey and Enrica Detragiache for her comments.

1 This effect does not imply that agents will increase investment at equilibrium, instead of reducing it, because their goal is to reallocate resources to the present so as to reduce the effect of the credit constraint on consumption, and increasing investment moves resources in the opposite direction.

${ }^{2}$ Lenders would find these financing premia optimal if they are extremely averse to non-repayment states as an agent with CRRA preferences, rather than being risk-neutral.

${ }^{3}$ Mendoza (2005b) provides a formal mathematical treatment of this setup.

${ }^{4}$ Since precautionary saving moves the long-run averages of debt and equity away from the "cliff's edge" where these conditions hold, Sudden Stops occur far from the means of the stochastic steady state. This implies that the model's business cycle moments are unaffected by Sudden Stops, and that Sudden Stops cannot be studied as features of nearsteady-state dynamics (as in Chari et al. (2005)). 


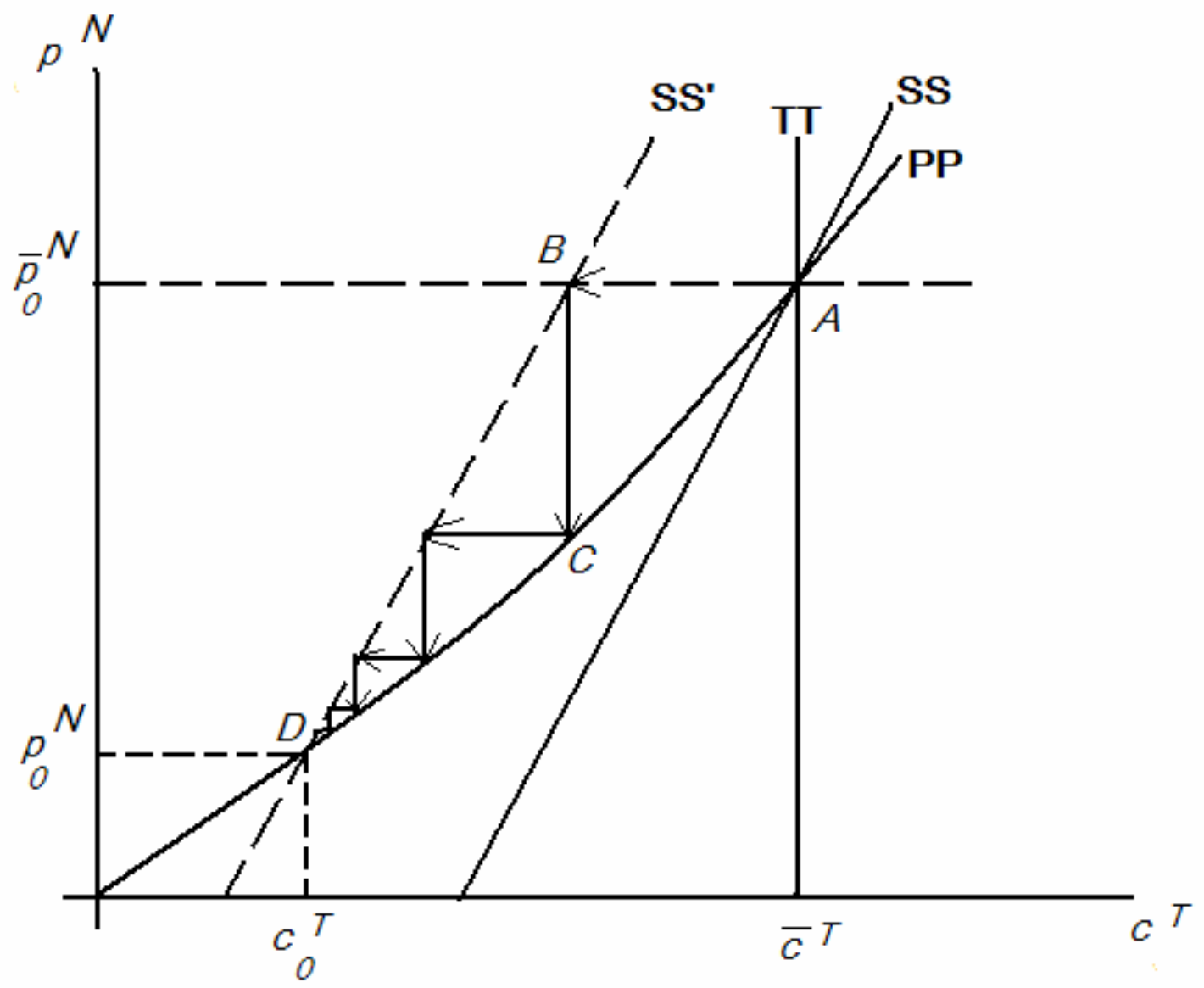

FIGURE 1. Debt-Deflation Equilibrium in the Economy with Liability Dollarization 
Figure 2. Sudden Stop Dynamics in Mendoza-Smith Model with Foreign Demand Elasticity of $1 / 2$ (percent deviations relative to economy with perfect credit markets)

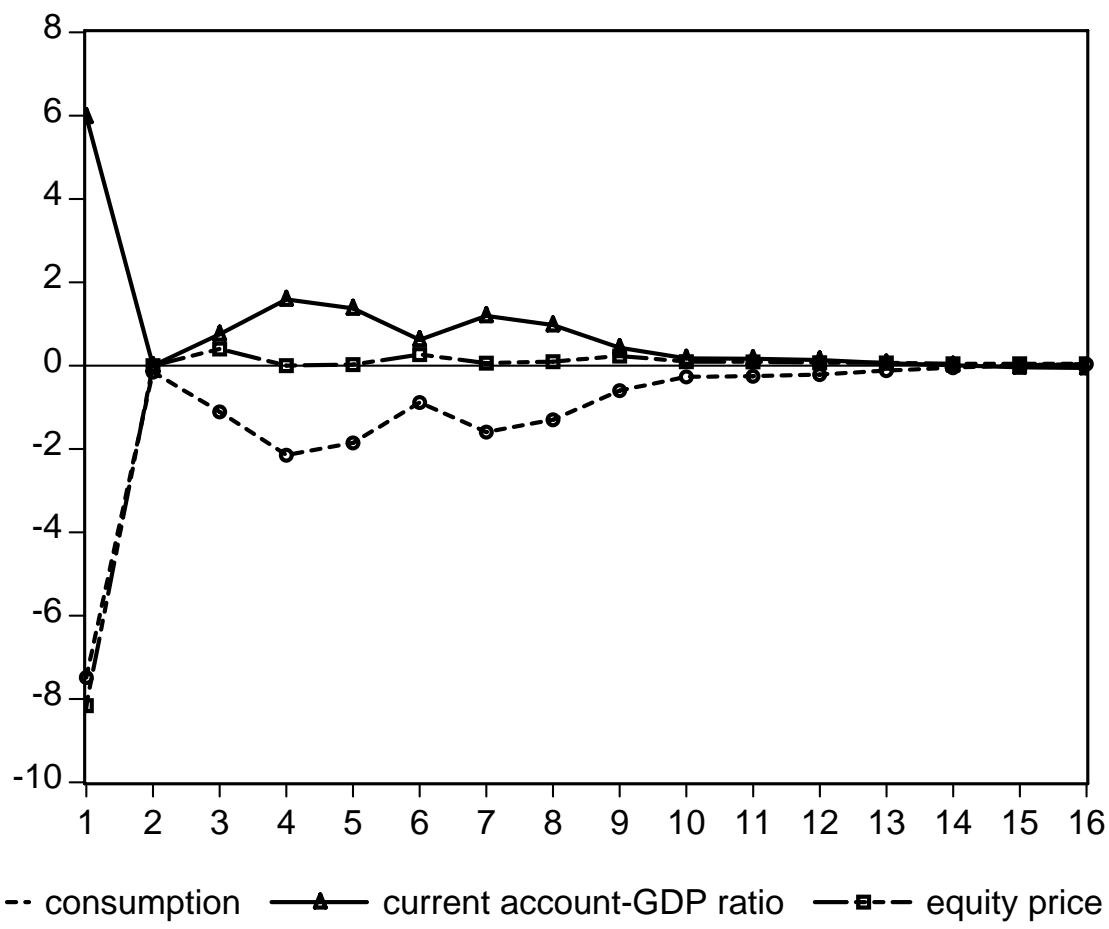

Note: Forecast functions conditional on a negative, one-standard-deviation productivity shock and a leverage ratio of $12.2 \%$ at date 1 (see Mendoza and Smith (2006) for details) . 
Figure 3. Leverage Ratios of Listed Corporations in South East Asia (Indonesia, Korea, Malaysia and Thailand)

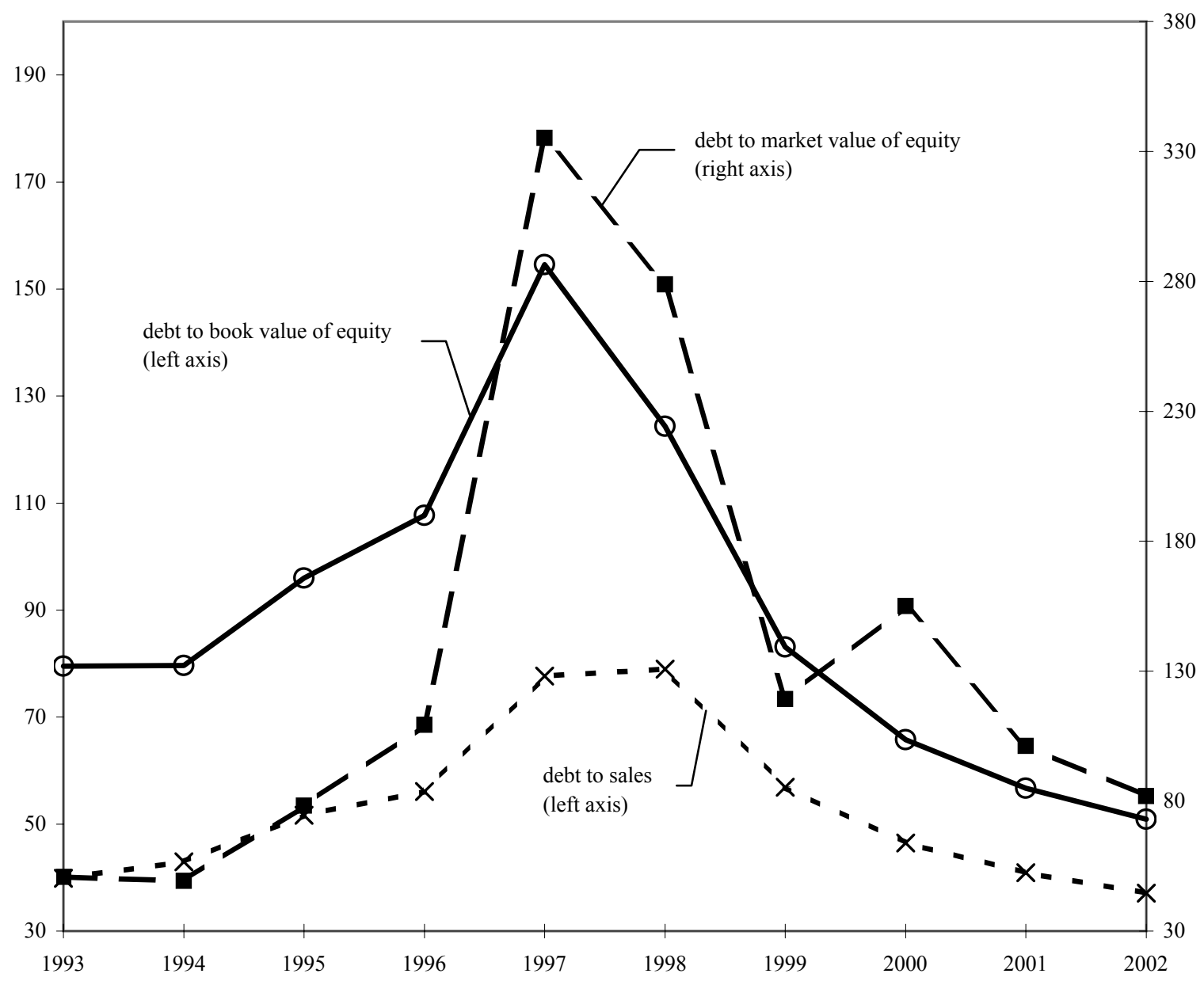

Note: Cross-country arithmetic average of median leverage ratios across all publicly listed corporations in each country. Data from Worldscope database. 